Article

\title{
Comparative Study of Natural Radioactivity and Radiological Hazard Parameters of Various Imported Tiles Used for Decoration in Sudan
}

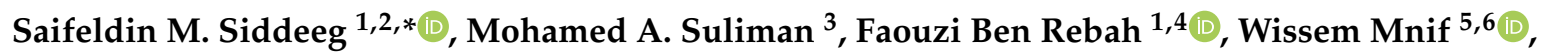 \\ Amel Y. Ahmed ${ }^{1,7}$ and Isam Salih ${ }^{1,8}$ (i) \\ 1 Department of Chemistry, College of Science, King Khalid University, P. O. Box 9004, \\ Abha 61413, Kingdom of Saudi Arabia; benrebahf@yahoo.fr (F.B.R.); amel_689@hotmail.com (A.Y.A.); \\ isamsalih@gmail.com (I.S.) \\ 2 Sudan Atomic Energy Commission, P. O. Box 3001, Khartoum 11111, Sudan \\ 3 Administration of Customs Laboratories and Environment, Radiation Protection and Nuclear Department, \\ Sudan Customs Authority, Khartoum 11111, Sudan; mohd200483@hotmail.com \\ 4 Higher Institute of Biotechnology of Sfax (ISBS), Sfax University, P. O. Box 263, Sfax 3000, Tunisia \\ 5 Faculty of Sciences and Arts in Balgarn, University of Bisha, P. O. Box 60, \\ Balgarn-Sabt Al Olaya 61985, Kingdom of Saudi Arabia; w_mnif@yahoo.fr \\ 6 LR11-ES31 Laboratory of Biotechnology and Valorisation of Bio-Geo Resources, Higher Institute of \\ Biotechnology of Sidi Thabet, BiotechPole of Sidi Thabet, University of Manouba, Biotechpole Sidi Thabet, \\ 2020 Ariana, Tunisia \\ 7 Department of Chemistry, Faculty of Science, King Faisal University, P. O. Box 400, \\ Al-Ahsa 31982, Saudi Arabia \\ 8 Physics Department, Taibah University, P. O. Box 344, AL Madinah Almunawarrah 41412, Saudi Arabia \\ * Correspondence: saif.siddeeg@gmail.com
}

Received: 11 November 2018; Accepted: 11 December 2018; Published: 13 December 2018

check for updates

\begin{abstract}
Various commercially imported ceramic materials used in the building of Sudanese dwellings were examined in order to determine their natural radioactivity and radiological hazard parameters. In this context, twenty-five different consignments were sampled and analyzed using $\left(3^{\prime \prime} \times 3^{\prime \prime}\right)$ sodium iodide gamma spectrometry system $\mathrm{NaI}(\mathrm{Tl})$. The identified average activity concentrations of ${ }^{238} \mathrm{U},{ }^{232} \mathrm{Th}$, and ${ }^{40} \mathrm{~K}$ were $183 \pm 70,51 \pm 44$, and $238 \pm 77 \mathrm{~Bq} / \mathrm{kg}$ dry-weights, respectively. A positive correlation between ${ }^{238} \mathrm{U}$ and ${ }^{232} \mathrm{Th}$ in the investigated samples was identified from the observed significant correlation $\left(R^{2}=0.8\right)$. Interestingly, a low $T h / U$ ratio $(\sim 0.3)$ was recorded, which could be related to the systematic loss of thorium during the fabrication process. The measured activity concentrations for these radionuclides were comparable with the reported data obtained from similar materials used in other countries showing similarity in ceramic materials used in buildings. Five different radiation indices, such as the average radium equivalent $\left(\mathrm{Ra}_{\mathrm{eq}}\right)$, the absorbed dose rate (D), the annual effective dose equivalent (AEDE), the external hazard index $\left(\mathrm{H}_{\mathrm{ex}}\right)$, and the radioactivity level index $\left(\mathrm{l}_{\gamma}\right)$, which indicate hazardous radiation, were estimated from these measurements. The obtained results revealed average values of $274 \pm 106 \mathrm{~Bq} / \mathrm{kg}$, $125 \pm 48 \mathrm{nGy} / \mathrm{h}, 1.23 \pm 0.48 \mathrm{mSv} / \mathrm{y}, 0.74 \pm 0.29$, and $0.94 \pm 0.37$, for $\mathrm{Ra}_{\mathrm{eq}}, \mathrm{D}, \mathrm{AEDE}, \mathrm{H}_{\mathrm{ex}}$, and $\mathrm{l}_{\gamma}$, respectively. The mean values of $\mathrm{Ra}_{\mathrm{eq}}$ and $\mathrm{H}_{\mathrm{ex}}$ were in good agreement with the international limits, while the means of $\mathrm{D}$ and $l_{\gamma}$ were higher than the universal values. Calculated AEDE in about $60 \%$ of the samples exceeded the universal limit of $1 \mathrm{mSv} / \mathrm{y}$ for the public exposure (maximum value of $2.16 \mathrm{mSv} / \mathrm{y}$ ). The investigated parameters were in the same range for the majority of imported samples; however, they were slightly higher than the locally produced ceramic, highlighting the importance of monitoring imported materials for their radioactivity contents.
\end{abstract}


Keywords: radioactivity concentration; radiological hazards; ceramic tiles; gamma ray spectrometry

\section{Introduction}

Naturally occurring radioactive materials (NORMs) are present at a low concentration in the environment [1]. These natural radionuclides, including long-lived radioactive elements, such as uranium, thorium, potassium, and the decay product radium, can be classified according to their origin and formation. The earth's crust is the source of these radionuclides and additionally, they could be part of all environmental compartments, even within the tissues of all living species [1]. NORMs occur in various natural materials (e.g., soils, water, gas, and non-metal minerals, including fertilizer raw materials, such as rock phosphate and apatite) [2,3]. Interestingly, it has been demonstrated that metal ores (tantalum, tin, niobium ores, gold, copper, etc.) are also associated with NORM [4]. Materials containing NORMs with an elevated radionuclides content which are used in industrial activities represent an environmental problem that needs to be addressed [5].

Generally, building materials are derived from rocks and soil which exhibit natural radioactivity related to the presence of uranium $\left({ }^{238} \mathrm{U}\right)$ decay-series and thorium $\left({ }^{232} \mathrm{Th}\right)$ decay-series, and the radioactive isotope of potassium $\left({ }^{40} \mathrm{~K}\right)$. The significant decay product in ${ }^{238} \mathrm{U}$ series is radium $\left({ }^{226} \mathrm{Ra}\right)$; for this reason, the series denoted the name radium decay. It has been demonstrated that people spend about $80 \%$ of their time indoors [6]. Human exposure to radiation is strongly related to the radioactivity content in building materials [7]. Therefore, the assessment of radioactivity in buildings is important to evaluate the radiation exposure. Among these decorative materials, ceramic tiles, which are manufactured using a mixture of earthly materials (shaped and heated at a high temperature), are used worldwide. The addition of zircon $\left(\mathrm{ZrSiO}_{4}\right)$ to ceramic significantly enhances the natural radioactivity concentration compared to the average value of the earth's crust. Moreover, the tiles processing enriches radionuclides in the final product [8].

The possibility of radioactive contamination or the presence of high concentrations of naturally occurring radioactive material may be high in these materials, which could affect human health and the environment $[9,10]$. This risk can be reduced by ensuring that the contaminated material is not exposed to the public, through the assessment of the quality of construction materials before they reach the market. The International Commission on Radiological Protection (ICRP) has developed a series of guidelines and technical documents related to the safety and dose limits permitted from naturally occurring radioactive materials [11]. The importing of naturally occurring radioactive materials is usually governed by various laws to ensure both quality and safety [12].

Sudan is a developing country, and in the last decades, it has been experiencing considerable development in infrastructure and constructions. This development is noticeable from the increasing number of buildings with a modern style, which requires the use of some imported building materials. Ceramic is used as a construction product to cover floors and walls, and as decoration material [5]. In Sudan, this is not limited to indoors, and outdoor yards and lounges also receive some interests of the use. For these purposes, Sudan imports ceramic from different countries, but mostly from China [13]. Ceramics are generally made from zirconium materials, which are made from natural ores that contain a trace amount of natural radioactive elements [14]. After the purification process, these traces are usually reduced to low levels.

The aim of this study is to explore the radiological hazards of ceramic used in buildings. The radioactivity level of imported ceramics used in Sudan as building materials will be evaluated and compared with global data. Finally, five selected hazard indices will be calculated to assess the exposure. 


\section{Materials and Methods}

\subsection{Sampling and Sample Preparation}

A total of 25 ceramics tiles, imported from China, were collected from different packages at the main seaport of Sudan, Port-Sudan City. The samples were obtained from different factories and include ceramic tiles used as a building material for walls and floors in Sudan.

About $0.7 \mathrm{~kg}$ in weight of each sample was crushed and samples were dried at $105^{\circ} \mathrm{C}$ for $3 \mathrm{~h}$ to obtain a dry sample. Then, to ensure that the secular equilibrium was reached, samples were sealed in Marinelli beakers for about four weeks to allow the daughters' decay rate to be same as that of the parent. The time of sealing is needed for confining radon gas within the available geometry to ensure the presence of all decay products.

\subsection{Measurements}

The radioactivity content and risk assessment were determined for the imported ceramic samples. Gamma spectrometry system model 802-4 NaI(Tl) crystal with a resolution range from 7.5 to $8.5 \%$ at a $662 \mathrm{kev}$ peak of Cs-137 connected to a personal computer analyzer using Win TMCA32 software was employed for these measurements. The detector system comprises built-in electronic modules plugged to a PC via a USB link. For measurements, a Marinelli beaker containing the sample was placed in the detector for three to six hours (depending on the counting statistics). The spectrum was stored in the computer and evaluated using "Win TMCA32 target" Gmbh software (Genie 2000, Canberra, Meriden, CT, USA). The system was regularly calibrated using a standard mixed gamma source in the same geometry. Additionally, measurement with an empty beaker taken regularly for background deduction was carried out. Quality control was run with the assistance of three referenced materials (RGU-1, RGTH-1, and RGK-1) obtained from the International Atomic Energy Agency (IAEA). To consider the errors associated with the radioactivity measurements, validation parameters such as the minimum detectable activity (MDA) of the detector and uncertainty (including precision and accuracy) were assessed during analysis [15]. The MDA was determined at a 95\% confidence level, while ten consecutive measurements were carried out to estimate the precision and accuracy associated with the activity concentrations of ${ }^{232} \mathrm{Th},{ }^{238} \mathrm{U}$, and ${ }^{40} \mathrm{~K}$, and the obtained data were satisfied.

The uranium (or radium) content of samples was evaluated via daughter isotopes that emit gamma rays and radium evaluated mainly from the gamma line of $609 \mathrm{keV}$ of Bi-214 (assuming secular equilibrium between parent nuclides $\left({ }^{238} \mathrm{U}\right.$ and ${ }^{226} \mathrm{Ra}$ ) and daughters). Thorium content was estimated from $239 \mathrm{keV}$ (gamma line) of $\mathrm{Pb}-212$ and potassium content was evaluated from $1460 \mathrm{keV}$ (gamma line). It should be noted that because of the poor resolution of NaI detectors, it was not possible to use low gamma energies of U-238 (63 keV) and Th-232 (92 keV) in this study.

\subsection{Assessment of Radiological Hazard}

To evaluate the radiological risk of exposure from the excess gamma radiation originating from ceramic used in building materials, some of radiological hazard indices have been calculated using Equations 1-5. The following section gives a brief description of these five indices.

\subsubsection{Radium Equivalent Radioactivity ( $\left(\mathrm{a}_{\mathrm{eq}}\right)$}

The radium equivalent activity ( $\left(\mathrm{a}_{\text {equ}}\right)$ is the sum of the activity of ${ }^{238} \mathrm{U},{ }^{232} \mathrm{Th}$, and ${ }^{40} \mathrm{~K}$ based on the assumption that $10 \mathrm{~Bq} / \mathrm{Kg}$ of ${ }^{238} \mathrm{U}, 7 \mathrm{~Bq} / \mathrm{Kg}$ of ${ }^{232} \mathrm{Th}$, and $130 \mathrm{~Bq} / \mathrm{Kg}$ of ${ }^{40} \mathrm{~K}$ produced the same $\gamma$-ray dose rates. The equivalent radioactivity is computed from the suggested Equation (1) $[14,16]$.

$$
\mathrm{Ra}_{\mathrm{equ}}(\mathrm{Bq} / \mathrm{Kg})=\mathrm{C}_{\mathrm{Ra}}+1.43 \mathrm{C}_{\mathrm{Th}}+0.077 \mathrm{C}_{\mathrm{K}}
$$

where $C_{R a}, C_{T h}$, and $C_{k}$ are the activity concentration of ${ }^{238} \mathrm{U}\left({ }^{226} \mathrm{Ra}\right),{ }^{232} \mathrm{Th}$, and ${ }^{40} \mathrm{~K}$ in $\mathrm{Bq} / \mathrm{Kg}$, respectively. To keep the external dose $<1.5 \mathrm{mGy} / \mathrm{h}$ [17], the highest value of $\mathrm{Ra}_{\mathrm{eq}}$ must be $<370 \mathrm{~Bq} / \mathrm{Kg}$. 


\subsubsection{The Absorbed Dose Rate}

The absorbed dose rate (D) in air (in Bq/ $\mathrm{kg}$ and at $1 \mathrm{~m}$ above the ground level) is associated with a specific activity concentration of ${ }^{238} \mathrm{U}\left({ }^{226} \mathrm{Ra}\right),{ }^{232} \mathrm{Th}$, and ${ }^{40} \mathrm{~K}$, indicating the effects of gamma radiation $[18,19]$. The value of $\mathrm{D}$ is defined by Equation (2):

$$
\mathrm{D}(\mathrm{nGy} / \mathrm{h})=0.462 \mathrm{C}_{\mathrm{Ra}}+0.604 \mathrm{C}_{\mathrm{Th}}+0.042 \mathrm{C}_{\mathrm{K}}
$$

\subsubsection{The Annual Effective Dose Equivalent}

The annual effective dose equivalent (AEDE) for the public or the worker in different samples $(\mathrm{mSv} / \mathrm{y})$ was estimated using Equation (3) [7].

$$
\operatorname{AEDE}(\mathrm{mSv} / \mathrm{y})=\left(0.46 \mathrm{C}_{\mathrm{Ra}}+0.79 \mathrm{C}_{\mathrm{Th}}+0.048 \mathrm{C}_{\mathrm{K}}\right) \times 8.76 \times 10^{-3}
$$

\subsubsection{The External Hazard Index}

The external hazard index $\left(\mathrm{H}_{\mathrm{ex}}\right)$ evaluates the radiation risk attributed to radioactive materials. The value of $\mathrm{H}_{\mathrm{ex}}$ is calculated using Equation (4) $[7,19]$.

$$
\mathrm{H}_{\mathrm{ex}}=\frac{\mathrm{C}_{\mathrm{Ra}}}{370}+\frac{\mathrm{C}_{\mathrm{Th}}}{259}+\frac{\mathrm{C}_{\mathrm{K}}}{4810}
$$

To consider the radiation hazard insignificant, the $\mathrm{H}_{\mathrm{ex}}$ value must be less than or equal to unity [16].

\subsubsection{The Radioactivity Level Index}

The radioactivity level index $\left(\mathrm{I}_{\gamma}\right)$ is used to estimate the rate of $\gamma$-radiation hazards linked with natural radionuclide in investigated samples. The $\mathrm{I}_{\gamma}$ is defined by Equation (5) [20].

$$
\mathrm{I}_{\gamma}=\frac{\mathrm{C}_{\mathrm{Ra}}}{300}+\frac{\mathrm{C}_{\mathrm{Th}}}{200}+\frac{\mathrm{C}_{\mathrm{K}}}{3000}
$$

\section{Results and Discussion}

\subsection{Radioactivity Contents in Ceramic Samples}

Natural ${ }^{238} \mathrm{U},{ }^{232} \mathrm{Th}$, and ${ }^{40} \mathrm{~K}$ were determined for the 25 -ceramic samples using the gamma spectrometry system. The results of the measurements are presented in Table 1 and Figures 1 and 2. The findings show that the activity concentrations varied from $93-318 \mathrm{~Bq} / \mathrm{kg}$, from 16-239, and from $126-384 \mathrm{~Bq} / \mathrm{kg}$ for ${ }^{238} \mathrm{U},{ }^{232} \mathrm{Th}$, and ${ }^{40} \mathrm{~K}$, respectively. The average values \pm standard deviations (SD) were found to be $183 \pm 70 \mathrm{~Bq} / \mathrm{kg}, 51 \pm 44 \mathrm{~Bq} / \mathrm{kg}$, and $238 \pm 77 \mathrm{~Bq} / \mathrm{kg}$ for ${ }^{238} \mathrm{U},{ }^{232} \mathrm{Th}$, and ${ }^{40} \mathrm{~K}$, respectively. Table 1 shows descriptive statistics where the parameters are presented at $<0.05$.

The obtained activity concentrations of ${ }^{238} \mathrm{U},{ }^{232} \mathrm{Th}$, and ${ }^{40} \mathrm{~K}$ were compared with the global average activity concentration values (50,50, and $500 \mathrm{~Bq} / \mathrm{kg}$ ) [7]. The results revealed that all samples contain ${ }^{238} \mathrm{U}$ (average $183 \pm 70 \mathrm{~Bq} / \mathrm{kg}$ ) higher than the typical world value by at least two times, and up to five times in about $25 \%$ of the studied samples (average of 3.6 higher). This higher ${ }^{238} \mathrm{U}$ is likely due to the source of the samples and processing composition. For ${ }^{232} \mathrm{Th}$, the majority of samples have values (average of $51 \pm 44 \mathrm{~Bq} / \mathrm{kg}$ ) close to global values, with the exception of one sample. It is also observed that the average concentration of ${ }^{40} \mathrm{~K}(238 \pm 77 \mathrm{~Bq} / \mathrm{kg})$ is lower than the corresponding typical world value. These results are relatively higher than the levels in previously investigated locally produced materials, particularly ${ }^{238} U[21,22]$. However, the activity concentrations of ${ }^{238} U$, ${ }^{232} \mathrm{Th}$, and ${ }^{40} \mathrm{~K} \mathrm{~Bq} / \mathrm{kg}$ of ceramic samples in the present study are comparable, with slight variations with other studies in some countries [21,23-27], as indicated in Table 2. 
Table 1. Activity concentrations of ${ }^{238} \mathrm{U},{ }^{232} \mathrm{Th}$, and ${ }^{40} \mathrm{~K}$ (in Bq/Kg) of various imported commercial tile samples used for decoration in Sudan.

\begin{tabular}{|c|c|c|c|}
\hline Tiles Samples & ${ }^{238} U$ & ${ }^{232} \mathrm{Th}$ & ${ }^{40} \mathrm{~K}$ \\
\hline 1 & $104 \pm 7.7$ & $239 \pm 5.6$ & $301 \pm 16$ \\
\hline 2 & $93 \pm 5.4$ & $16 \pm 4.1$ & $215 \pm 13$ \\
\hline 3 & $311 \pm 2.6$ & $93 \pm 6.7$ & $384 \pm 16$ \\
\hline 4 & $97 \pm 5.6$ & $24 \pm 4.0$ & $231 \pm 13$ \\
\hline 5 & $140 \pm 5.7$ & $38 \pm 4.3$ & $335 \pm 14$ \\
\hline 6 & $195 \pm 7.2$ & $51 \pm 5.2$ & $224 \pm 11$ \\
\hline 7 & $165 \pm 6.6$ & $35 \pm 5.3$ & $297 \pm 14$ \\
\hline 8 & $214 \pm 7.8$ & $54 \pm 5.8$ & $201 \pm 12$ \\
\hline 9 & $195 \pm 7.8$ & $54 \pm 5.9$ & $174 \pm 11$ \\
\hline 10 & $318 \pm 9.8$ & $84 \pm 7.3$ & $332 \pm 16$ \\
\hline 11 & $258 \pm 9.1$ & $70 \pm 6.5$ & $289 \pm 15$ \\
\hline 12 & $117 \pm 5.7$ & $32 \pm 4.3$ & $325 \pm 15$ \\
\hline 13 & $134 \pm 6.0$ & $29 \pm 4.6$ & $130 \pm 9.0$ \\
\hline 14 & $135 \pm 6.0$ & $25 \pm 4.5$ & $135 \pm 9.0$ \\
\hline 15 & $177 \pm 7.1$ & $30 \pm 5.1$ & $281 \pm 14$ \\
\hline 16 & $249 \pm 7.9$ & $54 \pm 6.5$ & $224 \pm 13$ \\
\hline 17 & $245 \pm 7.6$ & $39 \pm 6.2$ & $170 \pm 10$ \\
\hline 18 & $251 \pm 7.7$ & $41 \pm 6.4$ & $162 \pm 10$ \\
\hline 19 & $131 \pm 6.1$ & $26 \pm 4.7$ & $139 \pm 10$ \\
\hline 20 & $276 \pm 8.6$ & $68 \pm 6.1$ & $345 \pm 14$ \\
\hline 21 & $127 \pm 6.1$ & $23 \pm 4.8$ & $126 \pm 9.0$ \\
\hline 22 & $142 \pm 6.6$ & $34 \pm 4.8$ & $192 \pm 11$ \\
\hline 23 & $100 \pm 5.6$ & $20 \pm 4.4$ & $175 \pm 12$ \\
\hline 24 & $250 \pm 8.8$ & $68 \pm 6.2$ & $311 \pm 15$ \\
\hline 25 & $147 \pm 6.8$ & $31 \pm 5.2$ & $245 \pm 14$ \\
\hline Average & 183 & 51 & 238 \\
\hline Standard Error & 14 & 9 & 15 \\
\hline Median & 165 & 38 & 224 \\
\hline Standard Deviation & 70 & 44 & 77 \\
\hline Confidence Level (95\%) & 29 & 18 & 32 \\
\hline
\end{tabular}

Table 2. Comparative analysis of activity concentrations of ${ }^{238} \mathrm{U},{ }^{232} \mathrm{Th}$, and ${ }^{40} \mathrm{~K}$ (in Bq/Kg) in Bq/kg of commercial tiles used in various countries.

\begin{tabular}{|c|c|c|c|c|c|c|c|}
\hline \multirow{3}{*}{ Origin } & \multicolumn{6}{|c|}{ Activity Concentration (in Bq/Kg) } & \multirow{3}{*}{ References } \\
\hline & \multicolumn{2}{|c|}{${ }^{238} \mathrm{U}$} & \multicolumn{2}{|c|}{${ }^{232} \mathrm{Th}$} & \multicolumn{2}{|c|}{${ }^{40} \mathrm{~K}$} & \\
\hline & Range & Average & Range & Average & Range & Average & \\
\hline Sudan & 3-394 & 52.4 & $2.8-108.2$ & 20.6 & $82-1413$ & 206.9 & [21] \\
\hline Cuba & nd $^{1}$ & nd & $1.2-22$ & - & 9-857 & - & [23] \\
\hline Ghania & nd & nd & $18.13-38.18$ & 25.44 & $67.50-655.13$ & 233 & [24] \\
\hline Serbia & nd & nd & 50-101 & 65.5 & $560-1070$ & 841.25 & [25] \\
\hline Yemen & $0-560$ & 207.2 & $0-267$ & 75.2 & nd & $\mathrm{Nd}$ & [26] \\
\hline Nigeria & $37.5-241$ & 61.1 & $41.5-126.5$ & 70.2 & $270-940$ & 514.7 & [27] \\
\hline Present Study & $93-318$ & 183 & 16-239 & 51 & $126-384$ & 238 & - \\
\hline
\end{tabular}


Figure 1 shows a box-plot of ${ }^{238} \mathrm{U},{ }^{232} \mathrm{Th}$, and ${ }^{40} \mathrm{~K}$ activity concentrations, where the minimum, maximum, and means are presented. Distributions of the obtained content of the three radionuclides are non-normal. The figure shows that an outlier is noted for ${ }^{232} \mathrm{Th}$. Excluding this outlier, the average ${ }^{232} \mathrm{Th}$ concentration becomes $43 \mathrm{~Bq} / \mathrm{kg}$ (i.e., about the same order of magnitude). Although ${ }^{232} \mathrm{Th}$ is lower than ${ }^{238} \mathrm{U}$ (ratio $~ 0.28$ ), a significant correlation $\left(\mathrm{R}^{2}=0.83\right.$ ) between the two radionuclides was observed, with one exceptional outlier, as can be noticed from Figure 2. The low Th/U ratio (compared to natural normal values) indicates that natural and/or man-made change occurred to the material, where a high loss of Th occurred either during a natural process or at a fabrication phase of the ceramic.

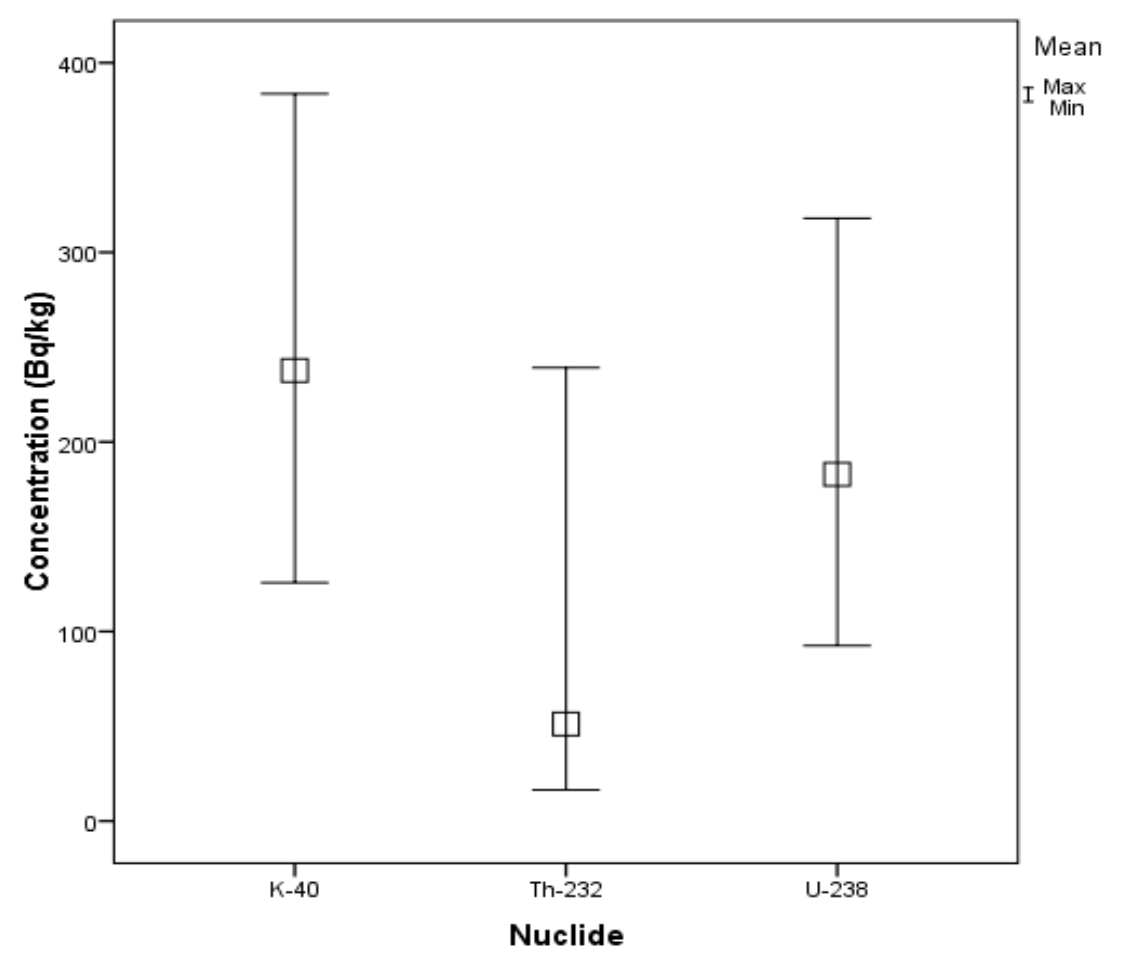

Figure 1. Mean and range of the three nuclides: ${ }^{238} \mathrm{U},{ }^{232} \mathrm{Th}$, and ${ }^{40} \mathrm{~K}$ (in Bq/kg).

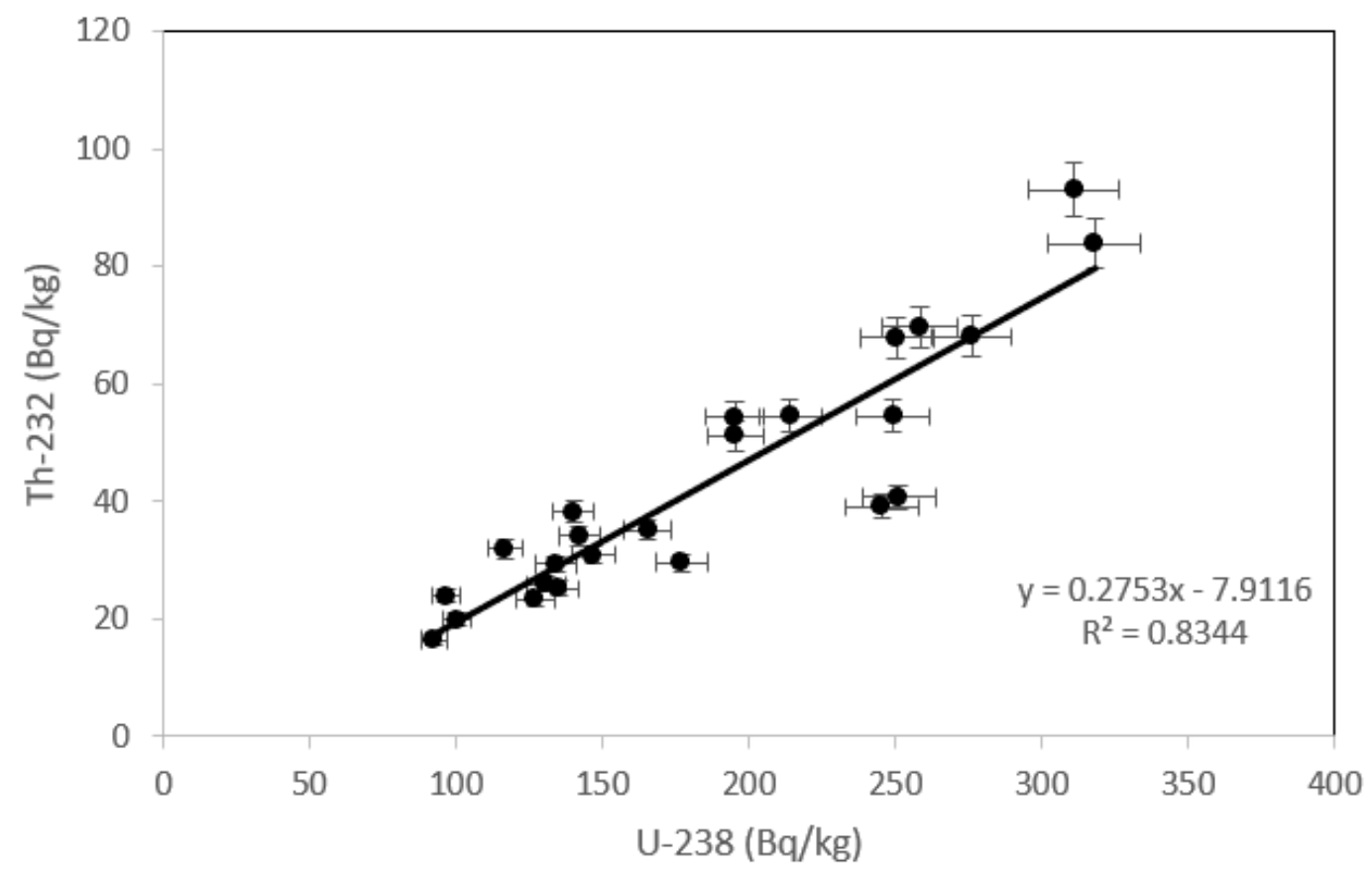

Figure 2. Correlation between ${ }^{238} \mathrm{U}$ and ${ }^{232} \mathrm{Th}$. 


\subsection{Assessment of Radiological Hazard}

The calculated results are presented in Table 3. In addition, the obtained data of the five radiation indices were compared with the recommended global data $[7,17]$, as described in the following sub-sections.

The activity concentrations' range of ${ }^{238} \mathrm{U}$ and ${ }^{40} \mathrm{~K}$ indicates that the maximum value of each radionuclide is approximately three to four times the minimum, while for ${ }^{232} \mathrm{Th}$, the activity concentration is widely scattered (Table 3 ).

Table 3. Radiation indices of various imported commercial tile samples used for decoration in Sudan.

\begin{tabular}{|c|c|c|c|c|c|}
\hline Tiles Samples & $\mathrm{Ra}_{\text {equ }}{ }^{1}(\mathrm{~Bq} / \mathrm{Kg})$ & $D^{2}(n G y / h)$ & $\operatorname{AEDE}^{3}(\mathrm{mSv} / \mathrm{yr})$ & $\mathrm{H}_{\mathrm{ex}}{ }^{4}$ & $1_{\gamma}^{5}$ \\
\hline 1 & 469 & 205 & 2.17 & 1.27 & 1.64 \\
\hline 2 & 133 & 62 & 0.60 & 0.36 & 0.47 \\
\hline 3 & 474 & 216 & 2.12 & 1.28 & 1.63 \\
\hline 4 & 149 & 69 & 0.67 & 0.40 & 0.52 \\
\hline 5 & 221 & 102 & 1.00 & 0.59 & 0.77 \\
\hline 6 & 286 & 131 & 1.27 & 0.77 & 0.98 \\
\hline 7 & 239 & 110 & 1.07 & 0.64 & 0.83 \\
\hline 8 & 307 & 140 & 1.37 & 0.83 & 1.05 \\
\hline 9 & 286 & 130 & 1.27 & 0.77 & 0.98 \\
\hline 10 & 463 & 211 & 2.06 & 1.25 & 1.59 \\
\hline 11 & 380 & 174 & 1.69 & 1.02 & 1.31 \\
\hline 12 & 187 & 87 & 0.85 & 0.51 & 0.66 \\
\hline 13 & 186 & 85 & 0.82 & 0.50 & 0.64 \\
\hline 14 & 181 & 83 & 0.80 & 0.49 & 0.62 \\
\hline 15 & 241 & 111 & 1.08 & 0.65 & 0.83 \\
\hline 16 & 344 & 157 & 1.53 & 0.93 & 1.18 \\
\hline 17 & 314 & 144 & 1.39 & 0.85 & 1.07 \\
\hline 18 & 322 & 147 & 1.42 & 0.87 & 1.09 \\
\hline 19 & 178 & 82 & 0.79 & 0.48 & 0.61 \\
\hline 20 & 400 & 183 & 1.78 & 1.08 & 1.38 \\
\hline 21 & 170 & 78 & 0.75 & 0.46 & 0.58 \\
\hline 22 & 206 & 94 & 0.92 & 0.55 & 0.71 \\
\hline 23 & 142 & 66 & 0.64 & 0.38 & 0.49 \\
\hline 24 & 371 & 170 & 1.66 & 1.00 & 1.28 \\
\hline 25 & 210 & 97 & 0.94 & 0.57 & 0.73 \\
\hline Range & $133-473$ & $62-216$ & $0.60-2.17$ & $0.36-1.28$ & $0.46-1.64$ \\
\hline Average \pm Std & $274 \pm 106$ & $125 \pm 48$ & $1.23 \pm 0.48$ & $0.74 \pm 0.29$ & $0.94 \pm 0.37$ \\
\hline
\end{tabular}

\subsubsection{Radium Equivalent Radioactivity $\left(\mathrm{Ra}_{\mathrm{eq}}\right)$}

The calculations of $\mathrm{Ra}_{\mathrm{eq}}$ reveal that the values ranged from 133 to $473 \mathrm{~Bq} / \mathrm{kg}$, with an average value of $274 \pm 106 \mathrm{~Bq} / \mathrm{kg}$ (Table 3). It is obvious that $80 \%$ of the samples have $\mathrm{Ra}_{\mathrm{eq}}$ values less than the maximum allowed value of $370 \mathrm{~Bq} / \mathrm{kg}$, reducing the radiological hazard in ceramic tiles used in buildings $[7,17]$. 


\subsubsection{The Absorbed Dose Rate}

The absorbed dose rate values ranged between $62-216 \mathrm{nGy} / \mathrm{h}$, with an average value of $125 \pm$ $48 \mathrm{nGy} / \mathrm{h}$ (Table 3). From Table 3, it is noticed that about $32 \%$ of obtained results were below or equal to the permissible average global value of $80 \mathrm{nGy} / \mathrm{h}$ [19].

\subsubsection{The Annual Effective Dose Equivalent}

The annual effective dose equivalent (AEDE) ranged between $0.60 \mathrm{mSv} / \mathrm{y}$ and $2.17 \mathrm{mSv} / \mathrm{y}$, with a mean value of $1.23 \pm 0.48 \mathrm{mSv} / \mathrm{y}$ (Table 3). The results of AEDE indicated that $60 \%$ of the estimated values are higher than the international recommended value $(1 \mathrm{mSv} / \mathrm{y})$ for the public exposure dose criterion [18].

\subsubsection{The External Hazard Index}

The range of computed $\mathrm{H}_{\mathrm{ex}}$ for ceramic samples was between 0.36 and 1.28, with a mean value of $0.74 \pm 0.29$ (Table 3). Interestingly, about $90 \%$ of the values are lower than unity, fitting well with the universal assigned value, showing that these materials are safe for building construction $[7,25]$.

\subsubsection{The Radioactivity Level Index}

$\mathrm{I}_{\gamma}$ values were between $0.47-1.64$, with a mean value of $0.94 \pm 0.37$ (Table 3). It is noticed that $\mathrm{I}_{\gamma}$ values were higher than unity $\left(\mathrm{I}_{\gamma}>1\right)$ in about $75 \%$ of the measured samples.

\section{Conclusions}

The radioactivity of the collected samples, from 25 consignments of ceramics imported to Sudan, was measured using $\gamma$-spectroscopy for radiation protection purposes as the material is used in a variety of dwellings and public buildings. Uranium content $\left({ }^{238} \mathrm{U}\right)$ was 3.6 times higher than the recommended international limits. However, thorium $\left({ }^{232} \mathrm{Th}\right)$ and potassium $\left({ }^{40} \mathrm{~K}\right)$ were within the levels. The high U/Th ratio (3.6) is attributed to the loss of thorium during fabrication of the ceramic. Investigations of hazard indices resulted as follows: Average radium equivalent activity $(274 \mathrm{~Bq} / \mathrm{kg})$ lies within the recommended limit $(370 \mathrm{~Bq} / \mathrm{kg}$ ). The absorbed dose rate average is $122 \mathrm{nGy} / \mathrm{h}$, which is more than twice the international average value of $55 \mathrm{nGy} / \mathrm{h}$. Annual effective dose equivalent showed higher values than the global recommended value of $1 \mathrm{mSv} / \mathrm{y}$ in fourteen samples. External hazard index, $\mathrm{H}_{\mathrm{ex}}$, is in good agreement with the specified limit (unity). $\mathrm{I}_{\gamma}$ values for all samples were higher than unity $(>1)$. Therefore, from the measures and calculated radiological properties, the samples showed clear variation. Finally, it could be concluded that the ceramic used in the decoration of building materials could be a source of radiation that contributes to the total annual dose rate of $\gamma$-radiation (by $23 \%$ ) for Sudanese dwellings and public buildings.

Author Contributions: Conceptualization, S.M.S., M.A.S.; methodology, M.A.S.; software, I.S. and M.A.S.; validation, S.M.S. and I.S.; formal analysis, M.A.S. and F.B.R.; investigation, A.Y.A. and W.M.; resources, W.M.; data curation, F.B.R., S.M.S. and I.S.; writing—original draft preparation, M.A.S.; writing-review and editing, W.M., I.S., F.B.R.; visualization, A.Y.A.; supervision, S.M.S.; project administration, W.M. and S.M.S.

Funding: This research received no external funding.

Acknowledgments: The authors would like to express their gratitude to King Khalid University, Saudi Arabia for providing administrative and technical support. The authors would also like to thank the Administration of Customs Laboratories and Environment, Radiation Protection and Nuclear Department, Sudan Customs Authority for facilitating the samples collection. We also appreciate the cooperation of Radiation Physics Institute at Atomic Energy Commission for providing the referenced materials. Likewise the authors thanks University of Bisha, Kingdom of Saudi Arabia.

Conflicts of Interest: The authors declare no conflict of interest. 


\section{References}

1. IAEA Safety Glossary. Terminology Used in Nuclear Safety and Radiation Protection; IAEA: Vienna, Austria, 2007.

2. Cañete, S.J.; Palad, L.J.; Enriquez, E.B.; Garcia, T.Y.; Yulo-Nazarea, T. Leachable 226Ra in Philippine phosphogypsum and its implication in groundwater contamination in Isabel, Leyte, Philippines. Environ. Monit. Assess. 2008, 142, 337-344. [CrossRef] [PubMed]

3. Hegedûs, M.; Tóth-Bodrogi, E.; Németh, S.; Somlai, J.; Kovács, T. Radiological investigation of phosphate fertilizers: Leaching studies. J. Environ. Radioact. 2017, 173, 34-43. [CrossRef] [PubMed]

4. Harlow, K. Naturally occurring radioactive materials and the regulatory challenges to the zircon industry. J. S. Afr. Inst. Min. Metall. 2017, 117, 409-413. [CrossRef]

5. USEPA. Evaluation of EPA's Guidelines for Technologically Enhanced Naturally Occurring Radioactive Materials (TENORM); Technical Report to Congress EPA 402-R-00-01; USEPA: Washington, DC, USA, June 2000.

6. Turhan, S.; Arikan, I.H.; Demirel, H.; Gungor, N. Radiometric analysis of raw materials and end products in the Turkish ceramics industry. Radiat. Phys. Chem. 2011, 80, 620-625. [CrossRef]

7. UNSCEAR. Sources, Effects, and Risks of Ionizing Radiation; Report to the General Assembly, with Scientific Annexes; United Nation: New York, NY, USA, 2000.

8. Konstantin, K. Radiological constraints of using building materials and industrial by-products in construction. Constr. Build. Mater. 2009, 23, 246-253.

9. Ballesteros, L.M.; Zarza, I.; Ortiz, J.; Serradell, V. Occupational exposure to natural radioactivity in a zircon sand milling plant. J. Environ. Radioact. 2008, 99, 1525-1529. [CrossRef] [PubMed]

10. Michael, P.; Leo, M.L.N. Radionuclide Concentration in Food and Environment; Taylor \& Francis Group: London, UK, 2007.

11. Hossen, A.; Ferdous, N. Determination of Radiological Hazards and the Transfer Factors of Radionulides from Soil to Vegetables in the Southwestern District of Bangladesh. J. Phys. Sci. 2015, 2, 83-98.

12. ICRP. Protection Against Radon-222 at Home and at Work. ICRP Publication 65. Ann. ICRP 1993, $23,1-45$.

13. Chris, A.; Abiodun, A.; Zhang, C.; Laura, B. Lesson Learning in the Case of China-Sudan and South Sudan Relations; China and Africa, Palgrave Macmillan: Beijing, China, 2018; pp. 179-208.

14. Beretka, J.; Mathew, P.J. Natural radioactivity of Australian building materials, Industrial Wastes and By-products. Health Phys. 1985, 48, 87-95. [CrossRef] [PubMed]

15. Currie, L.A. Limits for qualitative detection and quantitative determination, application to radioacitivity. Anal. Chem. 1968, 40, 586-593. [CrossRef]

16. Krieger, R. Radioactivity of construction materials. Betonwerk Fertigteil Tech. 1981, 47, 468-475.

17. UNSCEAR. Sources, Effects and Risks of Ionizing Radiations; Report to the General Assembly, with Scientific Annexes; United Nations: New York, NY, USA, 1998; pp. 42-85.

18. Joel, E.S.; Maxwell, O.; Adewoyin, O.O.; Ehi-Eromosele, C.O.; Saeed, M.A. Assessment of natural radionuclides and its radiological hazards from tiles made in Nigeria. Radiat. Phys. Chem. 2018, 144, 43-47. [CrossRef]

19. NEA-OECD. Exposure to Radiation from Natural Radioactivity in Building Materials; Report by NEA Group of Experts; OECD: Paris, France, May 1979.

20. UNSCEAR. Summary of Low Dose Radiation Effects on Health; Report of the General Assembly, with Scientific Annexes; United Nations: New York, NY, USA, 2010.

21. Eisa, S. Investigation of Natural Radioactivity in Building Materials commonly used in Sudan. Master's Thesis, Sudan Academy of Science, Khartoum, Sudan, December 2010.

22. Isam, S.; Sara, A.; Sahar, E.; Hajo, I. Radiation exposure of workers in storage areas for building aterials. J. Taibah Univ. Sci. 2014, 8, 394-400.

23. Brígido, F.O.; Montalván, E.A.; Rosa, S.R.; Tomás, Z.J.; Hernández, P.A. Natural Radionuclide content in some building materials and gamma dose rate in dwellings in Cuba. J. Environ. Radioact. 2008, 99, 1834-1837. [CrossRef] [PubMed]

24. Kpeglo, D.O.; Lawluvi, H.; Faanu, A.; Awudu, A.R.; Deatanyah, P.; Wotorchi, S.G. Natural Radioactivity and its Associated Radiological Hazards in Ghanaian Cement. Res. J. Environ. Earth Sci. 2011, 3, 161-166.

25. Jankovic, M.M.; Rajacic, M.M.; Rakic, T.M.; Todorovic, D.J. Natural radioactivity in imported ceramic tiles used in Serbia. Process. Appl. Ceram. 2013, 7, 123-127. [CrossRef] 
26. Amin, S.A.; Naji, M. Natural radioactivity in different commercial ceramic samples used in Yemeni buildings. Radiat. Phys. Chem. 2013, 86, 37-41. [CrossRef]

27. Maxwell, O.; Adewoyin, O.O.; Joel, E.S.; Ehi-Eromosele, C.O.; Akinwumi, S.A.; Usikalu, M.R.; Emenike, C.P.; Embong, Z. Assessment of natural radioactivity in various commercial tiles used for building purposes in Nigeria. J. Radiat. Res. Appl. Sci. 2018, 11, 225-231. [CrossRef] 